\title{
免疫賦活成分含有キトサンナノ粒子の調製と評価
}

\section{Preparation and evaluation of chitosan-based nanoparticles containing immunestimulating agents}

\author{
07119 \\ 研究代表者 星薬科大学医療薬剤学教室 教授 大 西啓 Hiraku Onishi
}

\begin{abstract}
In this work, chitosan-based nanoparticles were applied to enhance efficacy of the immunostimulating agents. Lactoferrin (LF) and fucoidan (FUC) were chosen as immunostimulating agents. As to LF, chitosan/alginate/calcium complex microparticles were prepared as its drug carrier. The microparticles had a size of $1-2 \mu \mathrm{m}$, and showed relatively high LF content. The LF content and release rate were depended on the concentration of the chitosan solution used for the treatment of microparticles. Efficacy was investigated by the pretreatment with oral administration to rats with carrageenan-induced edema. The microparticles exhibited better efficacy than LF solution. In addition, chitosan-based nanoparticles containing FUC were prepared and evaluated on the usefulness. From the particle characteristics, $\mathrm{N}$-trimethylchitosan (TMC)/FUC nanoparticles were considered to be possibly useful nanoparticles, rather than chitosan/FUC nanoparticles. TMC/FUC nanoparticles had a size of 320 $\mathrm{nm}$ and contained FUC at $47 \%(\mathrm{w} / \mathrm{w})$. Efficacy was examined by the pre-treatment or posttreatment with oral administration using mice with sarcoma-180 solid tumor. In both treatments, TMC/FUC nanoparticles exhibited better suppression of tumor growth than FUC solution. The nanoparticles were considered to enhance the antitumor efficacy due to the promotion of immune induction etc. These results suggested the chitosan-based micro- or nanoparticles should be available for the enhancement of the functions of immunomostimulating agents.
\end{abstract}

\section{研究目的}

近年, 医薬が進歩したとはいえ, 難治性あるいは慢 性の疾患が多く存在しており，それらに苦しむ患者は 多い。また，原因不明の疾患も多く，対症療法にとど まる場合が多いのが現状である。癌や免疫異常による 疾患に扔いては, 薬剤の長期使用で副作用が起こりや すく, QOLの悪化, 長期的治療の困難さが指摘され ている。このような中で, 代替医療やサプリメントと いった副作用の少ない, 長期的療法が注目されている。 筆者らのグループでは, 今回, 免疫系を介して有効性
を発揮することが知られているラクトフェリンとフコ イダンに着目した。

ウシラクトフェリン（ラクトフェリン）は, 経口投 与に扔いて炎症や細菌感染, ウイルス性疾患に対する 保護や改善効果を発揮することがマウス, ラットやヒ トにおいて報告されている。小腸粘膜のレセプターや 腸管免疫系の賦活化によることが考えられてい る ${ }^{1-3)}$ 。ラクトフェリンの小腸粘膜レセプターや腸管 免疫系への送達性の向上は, 有効性の改善につながる と考えられる ${ }^{4-5)}$ 。

さらに, 抗癌作用が期待されている機能性食品とし 
てフコイダンが知られている。フコイダンは，免疫賦 活作用や癌のアポトーシス, 新生血管抑制作用を有し, かつ安全性が高いために，長期的使用が可能であ $3^{6-8)}$ 。経口投与での免疫賦活には腸管免疫の賦活化 が考えられている。

ラクトフェリン，フコイダンはいずれも小腸粘膜, 腸管免疫系への効率的な送達が有効性の向上につなが ることが期待される。ナノ粒子，マイクロ粒子のよう な微小粒子は，小腸において，高い粘液浸透性，粘膜 上皮細胞への到達性や滞留性を有することが報告され ており ${ }^{9)}$, それらの生理活性物質の有効性向上が期待 される。本研究では, 経口投与微粒子剤形の開発を行 い，その有用性の検討を試みた。

\section{研究成果の概要}

\section{1．ラクトフェリン微粒子製剤の開発と有効 性の評価}

\section{1 はじめに}

ラクトフェリンの微粒子製剤化について，キトサン を基材に用いて検討を行ったが，放出制御が必ずしも 容易でないこと，キトサン微粒子は胃酸で膨潤溶解し やすいために腸溶性コーティング等の後処理が必要な こともあり，胃，腸全体で，微粒子状態を保ち，ラク トフェリンの保護が可能な微粒子の探索を行った。キ トサン／アルギン酸／カルシウムからなる微粒子は, イオン架橋により，かなり安定な微粒子を形成するこ とが報告されており ${ }^{10)}$ ，今回はこの複合体微粒子を利 用して, ラクトフェリンの微粒子殽形開発を試みた。

\section{2 実験方法}

キトサン /アルギン酸／カルシウム複合微粒子の調 製については，アルギン酸／カルシウム微粒子を液中 乾燥法により調製し，これをキトサン溶液処理する 2 段階の方法で調製した。アルギン酸ナトリム（Al-Na: 和光純薬工業 (株)，80-120cP） 300mgとウシラクト フェリン（LF：NRLファーマ（株））150mgを水20ml に溶解し，1000rpmで擋拌している1％セスキオレイ ン酸ソルビタン（SO-15）含有流動パラフィン $400 \mathrm{ml}$ 中に滴下し，1時間撹拌した。その後，10\%（w/v） 塩化カルシウム水溶液 $4 \mathrm{ml}$ 添加し，さらに15分間 擋拌した。その後, 擋找を止め, ロータリーエバポレ ーターを用いて, 減圧下, $37^{\circ} \mathrm{C} て ゙$ 乾燥を行った。乳化
状態が微粒子懸濁状になった時点で溶媒留去を止め, n一ヘキサンを添加して混和し，1500×gで10分間遠心 分離を行った。沈殿物は, $\mathrm{n}$-ヘキサンを用いて 3 回 洗浄した。デシケーター中で乾燥し，アルギン酸／カ ルシウム複合微粒子( $(\mathrm{Al} / \mathrm{Ca}-\mathrm{MP})$ を得た。 $\mathrm{Al} /$ Ca-MP中のLF含有率は，粒子を日局15の第 1 液中に 懸濁し，沈殿物を日局15の第 2 液に溶解し，それぞれ に溶解したLFの量をBCAプロテインアッセイにより 求め, 算出した。

$\mathrm{Al} / \mathrm{Ca}-\mathrm{MP}$ 800mgを0.5\%（w/v） キトサン（Ch： 大日精化(株), 超低粘度)の 1 \%酢酸水溶液に投入し, 1時間擋挥した。 $1500 \times \mathrm{g}$ で10分間遠心分離を行い, 沈殿物を水で 3 回洗浄し, デシケーター中で乾燥し, キトサンノアルギン酸／カルシウム複合微粒子（Ch/ $\mathrm{Al} / \mathrm{Ca}-\mathrm{MP}$ ）を得た。LF含有率は，酸酸水溶液と洗 浄液中のLF量をBCAプロテインアッセイにより求め, もとのLF量から差し引くことにより算出した。

粒子の性状は, 白金コーティング後に走査型電子顕 微鏡 $(\mathrm{JEOL}$ JSM-5600LV) を用いて観測し, 粒子径, 形状を調べた。また， Ch/ Al/Ca-MP 10mgを日局 15 の第1液3 mlに分散し, $37^{\circ} \mathrm{C}$ で毎分100回の振とう条件 で2時間インキュベートを行い，1500×gで10分間遠 心分離後, 沈殿物に日局15の第 2 液 $3 \mathrm{ml}$ を添加し, 5 時間同様にインキュベートを行った。その際, 一定 時間後に遠心分離し，上澄 $100 \mu \mathrm{l}$ を採取し，放出した LF量をBCAプロテインアッセイにより求めた。

得られた微粒子の効果を判定するために, カラゲニ ン浮腫に対する炎症抑制効果について検討した。浮腫 作成 5，3，1 日前に50mg LF eq./kg/dayの投与条件 で，微粒子の生理食塩液懸濁液， $\mathrm{LF}$ 生理食塩液の 水溶液, 生理食塩液（コントロール）をテフロンチュ ーブを装着した経ロゾンデを用いて胃内に投与した。 $1 \%$ \%ゲニンの生理食塩液溶液0.1ml 後肢足蹠皮 下に注入し，その後，その第一関節までの体積を測定 し，浮腫の大きさを調べた。また，初期放出の影響を 取り除くために，第1液で1時間インキュベートした後 の粒子を遠心分離して採取し，これを用いて同様にカ ラゲニン浮腫抑制効果を検討した。

\section{3 結果と考察}

$\mathrm{Al} / \mathrm{Ca}-\mathrm{MP}$ は全体として $90 \%$ 以上の回収率で得ら れ，LFもほぼ $90 \%$ 回収された。 $\mathrm{Ch} / \mathrm{Al} / \mathrm{Ca}-\mathrm{MP}$ に対す る粒子特性をTable 1に示した。平均粒子径 $1.65 \mu \mathrm{m}$ で LF含有率 $22 \%$ ものが得られた。粒子生成量が初期 
Table 1 Preparative conditions, yields and particle characteristics of $\mathrm{Ch} / \mathrm{Al} / \mathrm{Ca}-\mathrm{MP}$

\begin{tabular}{cccccccc}
\hline Product & $\begin{array}{c}\text { Al/Ca-MP } \\
(\mathrm{mg})\end{array}$ & $\begin{array}{c}05 \% \mathrm{Ch} \\
\text { solution } \\
\text { volume }(\mathrm{ml})\end{array}$ & $\begin{array}{c}\text { Produced } \\
\text { amount }(\mathrm{mg})\end{array}$ & $\begin{array}{c}\text { Yield } \\
(\%, \mathrm{w} / \mathrm{w})\end{array}$ & $\begin{array}{c}\text { LF content } \\
(\%, \mathrm{w} / \mathrm{w})\end{array}$ & $\begin{array}{c}\text { LF } \\
\text { recovery }(\%)\end{array}$ & $\begin{array}{c}\text { Mean particle } \\
\text { size }(\mu \mathrm{m})\end{array}$ \\
\hline $\mathrm{Ch} / \mathrm{Al} / \mathrm{Ca}-\mathrm{MP}$ & 800 & 340 & $295 \pm 5$ & $38 \pm 2$ & $22 \pm 5$ & $52 \pm 9$ & $1.65 \pm 0.15$ \\
\hline
\end{tabular}

Yield was calculated as the ratio of the product amount to the total amount of the used substances.

LF recovery was the ratio of the incorporated LF amount to the used LF amount.

Thee results are expressed as the mean \pm S.D. $(n=3)$.

A

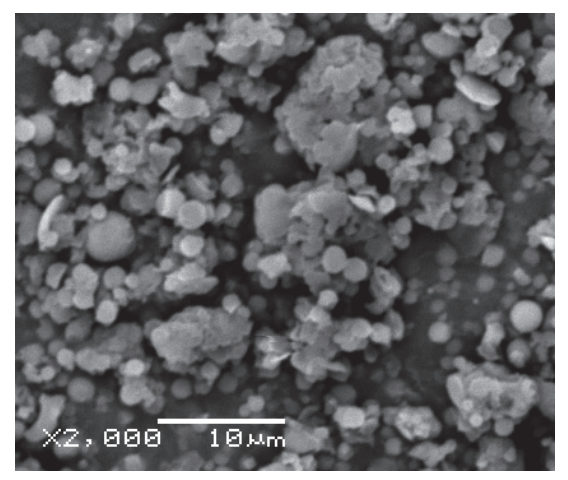

B

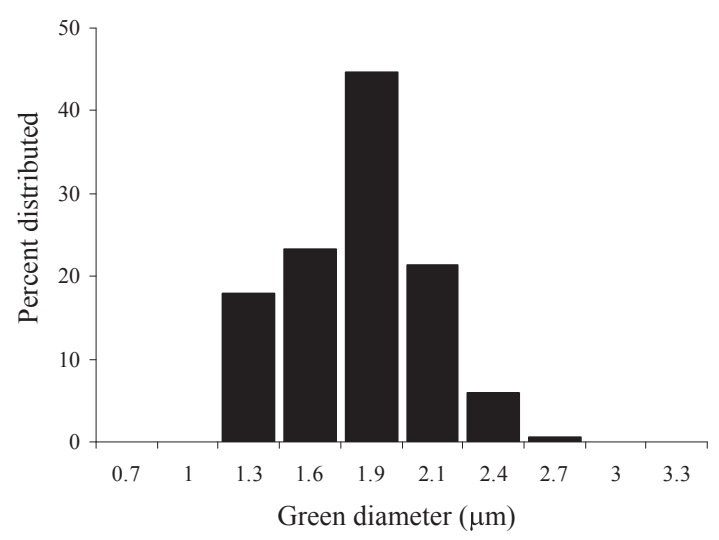

Fig.1 SEM image (A) and particle size distribution (B) of one lot of $\mathrm{Ch} / \mathrm{Al} / \mathrm{Ca}-\mathrm{MP} . \quad \mathrm{n}=150$ for $\mathrm{B}$.

量からかなり低下してしまうのは, キトサン溶液処理 時にAl/Ca-MP中に過剩に残存した塩化カルシウムが 溶け出すことによるものと考えられた。 Ch/ Al/ Ca-MPの粒子形状とサイズをFig.1に示した。Fig.2は, LFのCh/ $\mathrm{Al} / \mathrm{Ca}-\mathrm{MP}$ からの放出挙動を示す。1 時間で 約60\%が初期放出し, その後, 徐々に放出することが 示された。また, この放出試験の際, 第 1 液, 第 2 液 中いずれにおいても，粒子は懸濁状態を保つことが確 認された。Ch/Al/Ca-MPは，ほぼ球状で 1- 2 mmの サイズで，初期バーストはあるものの，LFを徐放す る微粒子として挙動することが確認された。なお, 本 調製条件では, サブミクロンオーダーの粒子を得るこ とは難しかった。今回のSO-15含有流動パラフィンの $\mathrm{W} / \mathrm{O}$ 乳化条件では難しいことが考えられた。しかし ながら, 得られた粒子サイズも十分小さく, 小腸上皮 や腸管免疫系への送達が可能であることが考えられ た。

動物実験においては，そのままの微粒子および初期 放出を取り除いた微粒子両方ついて検討をしたが, そ

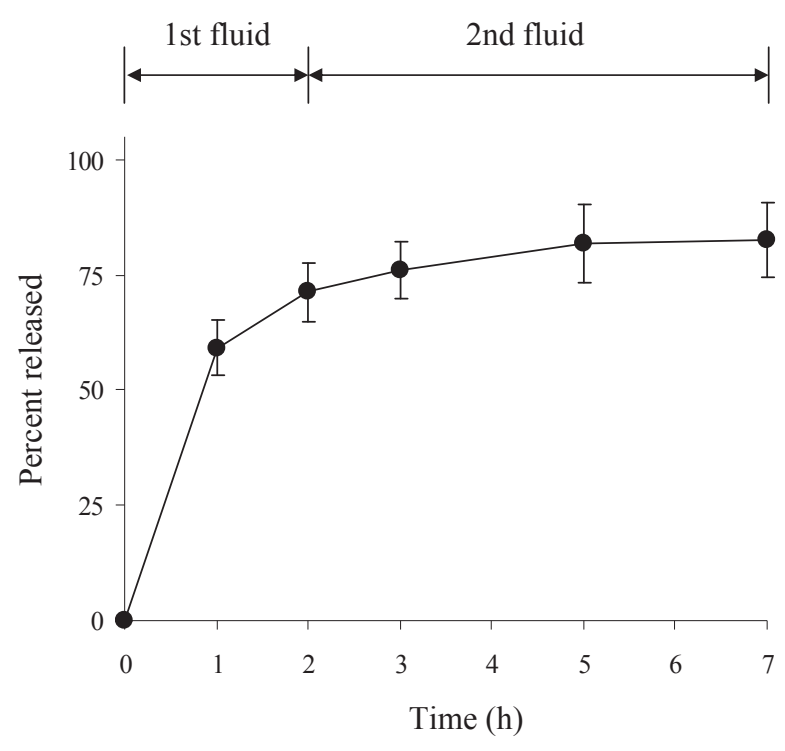

Fig.2 Release profiles of LF in the sequential incubation in JP15 1st fluid ( $\mathrm{pH}$ 1.2) for $2 \mathrm{~h}$ and subsequently in JP15 2nd fluid ( $\mathrm{pH}$ 6.8) for $5 \mathrm{~h}$. Each point represents the mean \pm S.D. $(n=3)$. 
れぞれの結果をFig.3，Fig.4に示した。いずれにおい ても，LF溶液群に比へ，微粒子群は優れた浮腫抑制 効果を示した。 $\mathrm{Ch} / \mathrm{Al} / \mathrm{Ca}-\mathrm{MP}$ は，徐放性微粒子とし て，優れたLFの効果を向上しうる製剂であることが 示された。

\section{2.トリメチルキトサン/フコイダン複合微 粒子の調製と有効性の評価}

\section{1 はじめに}

フコイダン（FUC）は，硫酸化多糖類で負電荷を 有して拉り，キトサンなどのポリカチオンとイオンコ ンプレックスを形成し，凝集することが知られている 11）。本研究では，キトサンおよびトリメチルキトサ ンを用いて，フコイダンとのイオン架橋型のナノ粒子 の調製を行うことを試みた。最初に, 流動パラフィン を分散媒とする液中乾燥法と水溶液中で混合するイオ ン架橋法を試みたが，液中乾燥法ではナノ粒子の調製 が困難であったため, イオン架橋法を用いて調製を行 うこととした。得られたナノ粒子について, in vitro とin vivoでフコイダンナノ粒子の有用性の評価を行 った。

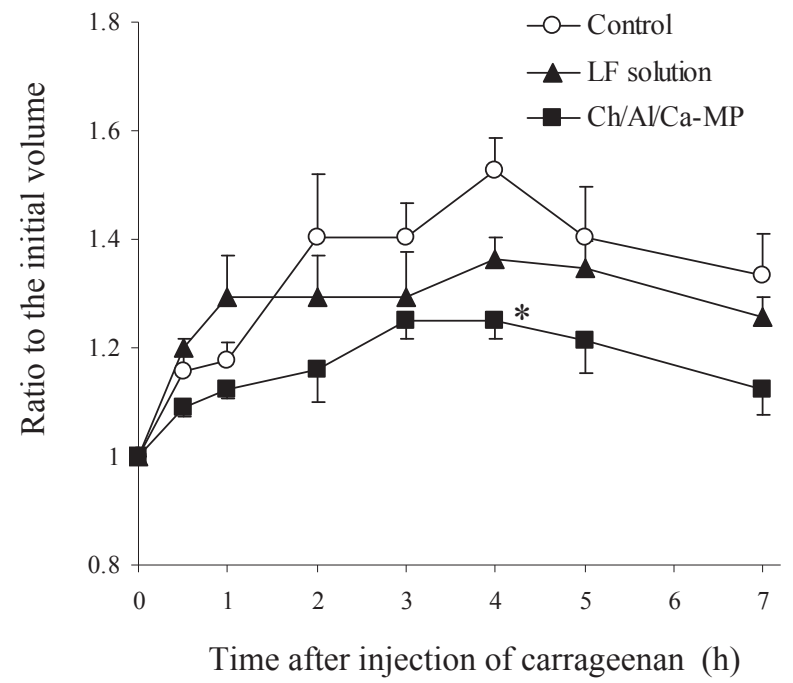

Fig.3 Change in right hind paw volume after intracutaneous injection of carrageenan to the footpad of the right hind paw in rats (250$260 \mathrm{~g})$. Samples were administered intragastrically at 50mg LF eq. $/ \mathrm{kg} \mathrm{5,} 3$ and 1 days before carrageenan injection (total dose $=3 \times 50 \mathrm{mg} \mathrm{LF}$ eq. $/ \mathrm{kg}$ ). The results are expressed as the mean \pm S.E. $(\mathrm{n}=3) .{ }^{*} P<$ 0.05 vs. Control (Dunnet t post hoc test).

\section{2 実験方法}

N-トリメチルキトサン（TMC）は，Sievalらの方 法を用いて調製したが，one-stepで得られた $8 \%$ トリ メチル化度のもの使用した。ナノ粒子調製は，TMC （10mg）を $20 \mathrm{ml}$ の水に溶解後, FUC（焼津水産化学 工業（株）） $10 \mathrm{mg}$ を含む水溶液 $10 \mathrm{ml}$ を摚挥下に徐々 に滴下した。得られた懸濁液を $670 \times \mathrm{g}$ で10min遠心し て，上澄みを採取した。上澄みはさらに，36000× $\mathrm{g}$ で20min遠心して，その沈殿物を採取し，これをFUC 含有 TMCナノ粒子（FUC/TMC-NP）とした。FUC 含有キトサンナノ粒子（FUC/CH-NP）については, $\mathrm{CH}$ （10mg）を $20 \mathrm{ml}$ の 1 \%酶酸水溶液に溶解し， FUC 滴下とそれ以降の操作は，FUC/TMC-NPと同様に行 い，調製した。

各粒子は，乾燥後に白金コーティングし，走査型電 子顕微鏡（JEOL JSM-5600LV）を用いて観測し，粒 子径，形状を調べた。また，粒子の水性懸濁液につい て，大塚電子社製の動的光散乱装置ELS-800を用いて 粒子サイズ，粒度分布を測定した。FUC/TMC-NP 中のFUC含有率については，FUC，TMCの元素分析 值から N/C比を調べ, 粒子のN/C比から, FUC と TMCの組成比を算出した (FUC/CH-NPについては,

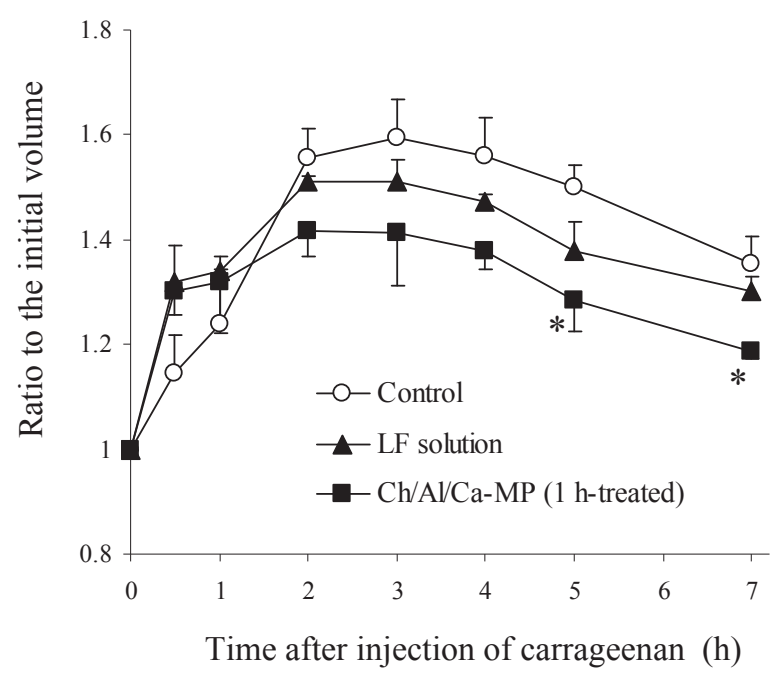

Fig.4 Change in right hind paw volume after intracutaneous injection of carrageenan to the footpad of the right hind paw in rats (180$200 \mathrm{~g})$. Samples were administered intragastrically at 50mg LF eq./ $\mathrm{kg} \mathrm{5,} 3$ and 1 days before carrageenan injection (total dose $=3 \times 50 \mathrm{mg} \mathrm{LF}$ eq. $/ \mathrm{kg}$ ). The results are expressed as the mean \pm S.E. $(n=3) .{ }^{*} P<$ 0.05 vs. Control (Dunnet t post hoc test). 
サイズが大きく，収率も低かったために，組成検討は 行わなかった)。

FUC/TMC-NPの有用性を検討するために，in vivo で抗腫瘍効果を検討した。約 $30 \mathrm{~g}$ の雄性ddyマウスを 用い, Sarcoma-180（東北大学加齢研より提供） $1 \times$ $10^{6}$ 個を腋下部皮下に移植して固形腫瘍担癌モデルと した。投与実験は, 腫瘍移植前投与 (Pre-treatment) と腫瘍移植後投与（Post-treatment）の 2 つのスケジ ユールで行った。すなわち, Pre-treatmentでは，移 植前13日から 1 日前までを隔日で計 7 回, 毎回 $15 \mathrm{mg}$ FUC eq./kgの dose で胃内に投与した。Posttreatmentでは，移植後1日目から13日目まで隔日で 計 7 回, 毎回 $15 \mathrm{mg}$ FUC eq./kgのdoseで胃内に投与 した。腫瘍サイズは, 移植 7 日目から腫瘍について長 径 $\times(\text { 短径 })^{2} / 2$ で求めた。

A

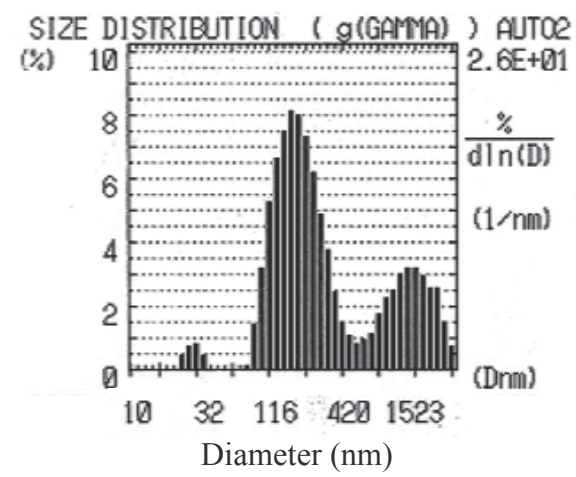

\section{3 結果と考察}

得られた各粒子の粒度分布をFig.5に, 走査電顕像 をFig.6に示した。 FUC/CH-NPは，平均粒子径が約 $2.8 \mu \mathrm{m}$ で，収率も約 $21 \%$ あり，いわゆるナノ粒子と して扱うことは難しいこと, 収率が低いことから, 更 なる検討を要することが見出されたため, これ以降の 検討は行わなかった。FUC/TMC-NPについては，平 均粒子径が $320 \mathrm{~nm}$ とナノオーダーで, 収率も比較的高 く, FUC含有率 $47 \%$, 封入効率 $34 \%$ あ゙あり, ナノ粒子 として優れていることが認められた（Table 2)。

動物実験による薬効評価については, Fig.7に結果 を示した。いずれに押いても, コントロール群に比べ, FUC溶液，FUC/TMC-NPいずれも腫瘍サイズの抑制 傾向を示した。また，FUC/TMC-NPはFUC溶液より も高い腫瘍増殖抑制を示し、コントロールに対しては 有意に抑制した。同時に体重測定を行ったが，いずれ

B

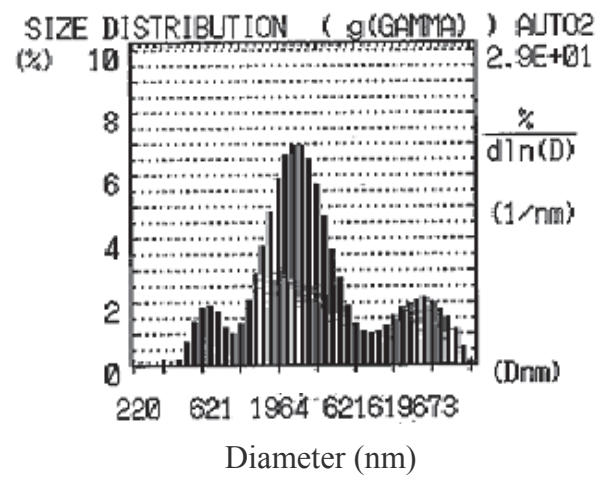

Fig.5 Size distribution profiles of FUC/TMC-NP (A) and FUC/CH-NP (B) in dynamic light scattering.

A

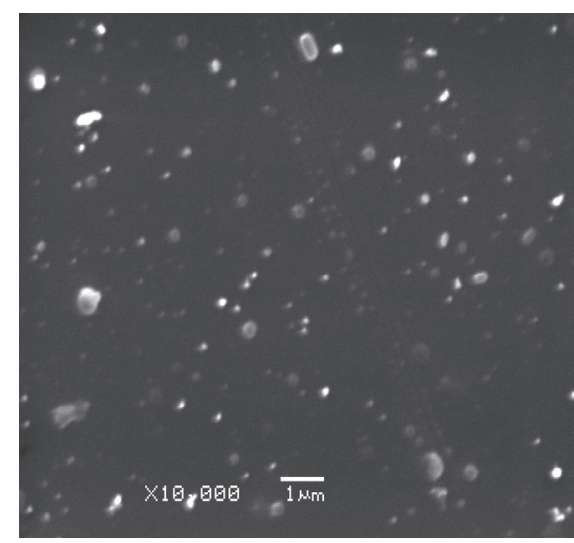

$\mathrm{B}$

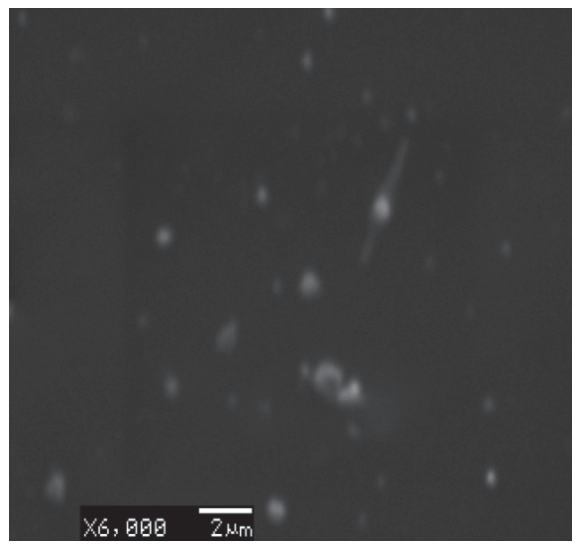

Fig.6 Scanning electron micrographs of FUC/TMC-NP (A) and FUC/CH-NP (B). The length of the white bar is $1 \mu \mathrm{m}$ and $2 \mu \mathrm{m}$ in $\mathrm{A}$ and $\mathrm{B}$, respectively. 
Table 2 Particle characteristics of FUC/TMC-NP

\begin{tabular}{cccc}
\hline $\begin{array}{c}\text { Particle size } \\
(\mathrm{nm})\end{array}$ & $\begin{array}{c}\text { Total yield } \\
(\%)\end{array}$ & $\begin{array}{c}\text { FUC content } \\
(\%, \mathrm{w} / \mathrm{w})\end{array}$ & $\begin{array}{c}\text { FUC loading efficiency } \\
(\%)\end{array}$ \\
\hline $325 \pm 36$ & $35.7 \pm 0.8$ & $46.9 \pm 1.6$ & $33.5 \pm 1.9$ \\
\hline
\end{tabular}

The results are expressed as the mean \pm S.D. $(n=3)$.

A

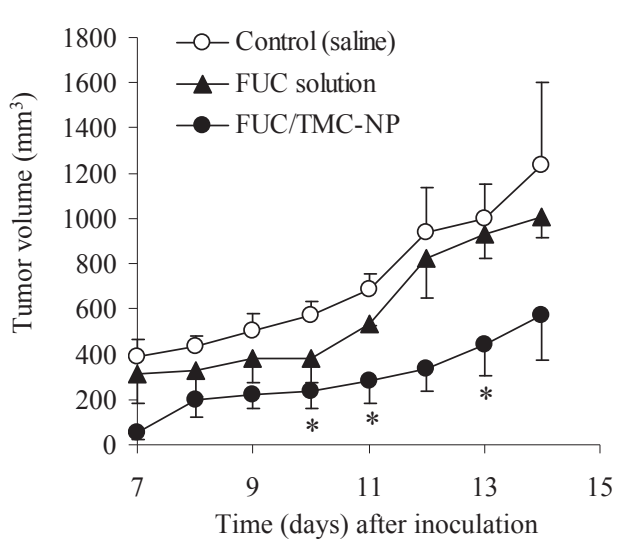

B

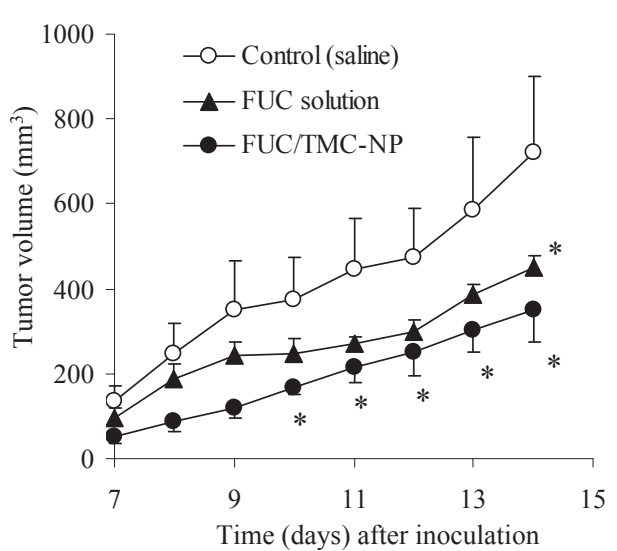

Fig.7 Tumor growth profiles in mice bearing S-180 by pre-treatment (A) and post-treatment (B). The results are expressed as the mean \pm S.E. $(n=3)$. The error bar is not described if it is smaller than the symbol. ${ }^{*} p<0.05$ vs. Control.

の群においても体重低下は認められず，毒性は少ない ことが示唆された。Pre-treatmentにおいて高い抑制 効果を示したことから，FUC/TMC-NPは免疫増強効 果を高める可能性があるものと考えられた。また，移 植後投与でもFUC/TMC-NPは，効果を増強する可能 性があると推察され，新生血管抑制やアポトーシス誘 発効果への影響も示唆された。今後詳細なメカニズム についての検討が望まれるが，FUC/TMC-NPは， FUCの抗腫瘍効果を高める微粒子剂形として有用で ある可能性が示唆された。

\section{参考文献}

1) Wakabayashi H., Abe S., Teraguchi S., Hayasawa H., Yamaguchi H. Inhibition of hyphal growth of azoleresistant strains of Candida albicans by triazole antifungal agents in the presence of lactoferrinrelated compounds. Antimicrob. Agents Chemother. 42 (7), 1587-1591 (1998).

2 ) Takakura N., Wakabayashi H., Ishibashi H., Teraguchi S., Tamura Y., Yamaguchi H., Abe S. Oral lactoferrin treatment of experimental oral candidiasis in mice. Antimicrob. Agents Chemother., 47(8), 2619-2623 (2003)

3 ) Ishikado A., Imanaka H., Takeuchi T.. Harada E., Makino T. Liposomalization of lactoferrin enhanced it's anti-inflammatory effects via oral administration. Biol. Pharm. Bull., 28 (9), 1717-1721 (2005).

4 ）木元博史, ラクトフェリン腸溶錠により血清脂質の改 善が認められた症例, Milk Science, 53(4), 313-314 (2004).

5 ) Suzuki Y.A., Lopez V., Lönnerdal B. Mammalian lactoferrin receptors: structure and function. Cell Mol. Life Sci., 62 (22), 2560-2575 (2005).

6 ) Koyanagi S., Tanigawa N., Nakagawa H., Soeda S., Shimeno H. Oversulfation of fucoidan enhances its anti-angiogenic and antitumor activities. $\mathrm{Bi}{ }^{\circ} \mathrm{C}$ hem. Pharmacol., 65(2):173-179 (2003).

7 ) Maruyama H., Tamauchi H., Hashimoto M., Nakano T. Antitumor activity and immune response of Mekabu fucoidan extracted from Sporophyll of Undaria pinnatifida., In Vivo, 17(3), 245-249 (2003).

8 ) Hyun J.H., Kim S.C., Kang J.I., Kim M.K., Boo H.J., Kwon J.M., Koh Y.S., Hyun J.W., Park D.B., Yoo E.S., 
Kang H.K. Apoptosis inducing activity of fucoidan in HCT-15 colon carcinoma cells., Biol. Pharm. Bull., 32 (10), 1760-1764 (2009).

9) Kawashima Y., Yamamoto H., Takeuchi H., Kuno Y. Mucoadhesive DL-lactide/glycolide copolymer nanospheres coated with chitosan to improve oral delivery of elcatonin., Pharm. Dev. Technol., 5(1), 7785 (2005)

10) Wittaya-areekul S., Kruenate J., Prahsarn C. Preparation and in vitro evaluation of mucoadhesive properties of alginate/chitosan microparticles containing prednisolone., Int. J. Pharm., 312(1-2):113118 (2006).

11) Nakamura S., Nambu M., Ishizuka T., Hattori H., Kanatani Y., Takase B., Kishimoto S., Amano Y., Aoki H., Kiyosawa T., Ishihara M., Maehara T. Effect of controlled release of fibroblast growth factor-2 from chitosan/fucoidan micro complex-hydrogel on in vitro and in vivo vascularization., J. Biomed. Mater. Res. A, 85(3), 619-627 (2008).

\section{発表論文}

1) Koyama K., Onishi H., Sakata O., Machida Y. Preparation and in vitro evaluation of chitosan- coated alginate/calcium complex microparticles loaded with fluorescein-labeled lactoferrin., Yakugaku Zasshi., 129 (12), 1507-1514 (2009).

2) Onishi H., Koyama K., Sakata O., Machida Y. Preparation of chitosan/alginate/calcium complex microparticles loaded with lactoferrin and their efficacy on carrageenan-induced edema in rats., Drug Dev. Ind. Pharm., 36 (8), 879-884 (2010).

3 ) Hayashi K., Onishi H., Sasatsu M., Machida Y. Preparation and Antitumor Effect of N-Trimethylchitosan/ Fucoidan Complex Nanoparticles. Curr. Nanosci., submitted.

\section{学会発表}

1) Hayashi K., Onishi H., Sasatsu M., Machida Y. Preparation and evaluation of $\mathrm{N}$-trimethylchitosan nanoparticles containing fucoidan., $68^{\text {th }}$ International Congress of FIP (2008).

2 ）大西 啓, 小山憲一, 町田良治. ラクトフェリン経口 投与のための微粒子製剤開発, 日本薬学会第129年会 (2009).

3 ）大西 啓, 小山憲一, 坂田 修, 町田良治. ラクトフ エリン含有微粒子製剤の調製と有効性の検討，第24回 キチンキトサンシンポジウム (2010) 